Милица Кривокапић

Универзитет у Београду

Филолошки факултет

докторанд
027.54(497.11)

https://doi.org/10.18485/melissa.2017.16.1.ch19

\title{
ЗНАЧАЈ И УЛОГА ЗАВИЧАЈНОГ ФОНДА
}

\section{Сажетак}

Очување нашег културног идентитета требало би да буде један од приоритета нашег друштва. Завичајни фондови омогућавају да наше материјално наслеђе буде сачувано на адекватан начин. Битно је на правилан начин очувати књижну и некњижну грађу једног региона. Морају да се остваре сви неопходни услови: обезбеде просторије, одређена температура, влажност ваздуха, стручан кадар, како би грађа остала у употребљивом облику. Грађа сачувана у поменутим фондовима често употпуњује слику и даје контекст приликом истраживања различитих периода и личности, а многи примерци и сами могу бити предмет анализе. Наравно, предстваљају изузетно наслеђе за будуће генерације.

Упознавање са локалном заоставштином доводи до развијања односа према наслеђу, идентитету и ентитету, нарочито је захвално за мултиетничке средине, јер је познатно да људи гаје предрасуде о другим групацијама, јер о њима знају недовољно. Значај и улога завичајног фонда је велика, јер ствара мост са прошлошћу и темељ за будућност.

Кључне речи: завичај, фондови, књижна грађа, некњижна грађа, библиотека

\section{1. Опште карактеристике завичајних фондова}

Чување и складиштење књига важно је за очување националног идентитета и упознавање других култура кроз њихову писану заоставштину. Позната је људска потреба да за собом остави трајни записани траг, да би будућим генерацијама оставили поруке, искуства, сазнања. Прве библиотеке појавиле су се 3000 година пре нове ере у сумерским храмовима, а постоје и подаци о асирским збиркама у 
Месопотамији још у 8. веку пре нове ере, док александријска библиотека датира из 3. века пре нове ере. Кроз историју је познато да су изузетно место у друштву заузимале библиотеке попут Краљевске библиотеке у Дамсаку и библиотеке Римског царства. Статус библиотеке као институције у друштву зависио је и од односа владара према њима. У средњем веку хришћански манастири одиграли су велику улогу да сачувају национално благо. „У ренесансном периоду библиотеке су одраз хуманистичке мисије у једнакој мери као и потврде персоналног статуса њиховог у друштву признатог и материјално веома ситуираног власника." ${ }^{\prime 1}$

Прве библиотеке на нашим просторима биле су при манастирима, поред обавезних књига за литургијске потребе поседовали су и друга дела. Историјски подаци сведоче да је било манастира са веома богатим библиотекама. Прва библиотека у Србији основана је 1832. године из које је проистекла Народна библиотека.

Библиотеке великим делом имају сличну организацију фондова, оно што сваки крај чини јединственим јесте завичајна грађа. Потреба да се сачувају и негују духовне различитости једног краја довела је до отварања завичајних библиотека, које су чувари националног и културног блага и подсетник друштву ко смо и како нам је наслеђе остављено. Завичајне библиотеке су стуб сећања једног друштва. Сва књижна и некњижна грађа која је претекла зубу времена захтева адекватно чување како бисмо и ми будућим генерацијама омогућили да се живописно упознају са културним наслеђем свога краја. Самостално организоване или у оквиру народних библиотека, као завичајно одељење, завичајни фонд најтипичније, најоргиналније и најбоље описује духовни и културни живот једне средине. Завичајне библиотеке дају печат различитости свакој библиотеци. Завичајни фондови су скуп науке, историје, економије, привреде једне територије.

„Завичајне колекције при јавним библиотекама оформљују се како би испуњавале три основна задатка:

- прикупљање и обраду свих штампаних и на други начин умножених материјала који су персонално, садржински, географски, историјски или етнички везани за завичај;

1 Александра Вранеш, Љиљана Марковић, Јасна Јанићијевић, Етичност у науци и култури, стр. 85, Филолошки факултет Универзитета у Београду, Белпак, 2009. године 
- чување и заштиту на адекватан начин свих библиотечких јединица у завичајном фонду;

- доступност публикација и инфрормација у едукативне, научне, културолошке, маркетиншке сврхе."2

Основни задатак и мисија завичајних библиотека је развијање свести о културном наслеђу, разумевању уметности, научних достигнућа и открића. Завичајне библиотеке чувају од заборава вредно наслеђе једне територије, које треба да служи будућим генерацијама и као подсетник на генерације које су живеле у једном периоду када се грађа сакупљала. Оне су значајне за праћење политичког, привредног и културно-просветног развоја у прошлости.

„Копенхагенском декларацијом из 1998. године, базираним на Унесковом Манифесту о библиотекама, истакнуто је да јавне библиотеке представљају памћење свих народа, друштва, заједница, институција и појединаца. Управо својим завичајним фондовима јавне библиотеке највише одговарају постављеном захтеву. “3

Три су основна револуционарна проналаска условила развој библиотеке: рођене су проналаском писма, стасале су уз технику штампања, сазреле су кроз примену Интернета. ${ }^{4}$

\section{1. Настанак завичајних библиотека}

Прва замисао за покретање завичајних библиотека јавила се између два светска рата, али бржи развој почео је после Другог светског рата. Код нас се јавила у Београду 1929. године на предлог др Милосава Стојадиновића, тадашњег потпредседника општине Београда. Одмах је почело прикупљање грађе, основани су фондови и 11. јануара 1931. свечано је отворена једна од најстаријих установа културе, Библиотека и музеј града Београда. Библиотеке у Србији између два светска рата биле су у лошем стању.

2 Александра Вранеш, Љиљана Марковић, Љиљана Бајић, Стана Смиљковић, Школа и библиотека, стр. 38, Филолошки факултет Универзитета у Београду, Белпак, 2010. године

3 Александра Вранеш, Рукописна грађа у завичајним фондовима, стр. 62, Зборник радова: Стање и перспецтиве развоја завичајних фондова Бајић, Чачак, 2004. године Ибид 1, стр. 86 
Како би се ускладили са светским библиотекарством и схватајући значај завичајног фонда Народна библиотека Србије упућује 1953. године предлог свим народним библиотекама да почну са формирањем завичајних фондова. Исте године на Првом саветовању библиотекара донет је закључак: „Све библиотечке установе, на чијој територији је у времену од 1884. до 1918. године постојала издавачка делатност, треба да прикупе све књиге, брошуре, новине, и часописе који ће се користити за научне и библиографске сврхе... среска библиотека би могла да приступи прикупљању и чувању публикација које би омогућиле проучавање географских, историјских, етнографских, привредних и

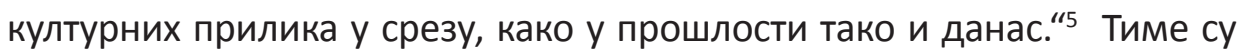
тачно одређени садржаји и намена будућих завичајних фондова.

Основне карактеристике завичајних фондова су да сачувају културну баштину локалне средине, односно региона. Формирањем Библиотечког центра Народне библиотеке Србије 1954. године одржано је Друго саветовање библиотекара и књижара на коме је поред осталих питања наглашено да је „....израда локалних библиографија и прикупљање грађе о одређеном месту обавеза свих библиотекара."

Формирање и чување завичајног фонда одређено је члановима и поглављима Закона о библиотекама број 48 члан 38, из 1960. године, све до 1994. године, Правилима о раду матичних библиотека и Дестогодишњим програмом развоја библиотекарства 19711980. године. Било је много недоумица на које су библиотекари наилазили, као и озбиљних проблема што се види и по семинарима и саветовањима која су одржана у периоду од 1960-1970. године два пута у Пожаревцу, затим у Светозареву, Врању, Ваљеву, Крагујевцу, Титовом Ужицу, Пироту, Смедереву. Без обзира на проблеме у том периоду почело је прво формирање завичајних библиотека у Крагујевцу, Пожаревцу, Титовом Ужицу. Оптимистички је кренуло са формирањем завичајних библиотека усвајањем Дестогодишњег програма развоја библиотекарства од 1971-1980. године и Пројекције развоја библиотекарства, ближе је одређена улога завичајних фондо-

5 Десанка Стаматовић, Завичајни фондови данасм стр. 12, Бајић, Зборник радова: Стање и перспецтиве развоја завичајних фондова, Чачак, 2004. године ибид 5 
ва, не само у односу на заштиту и чување националног фонда, већ и у односу на развој јединственог библиотечко-информационог система и место општинске народне бибиблиотеке у њему. ${ }^{7}$ Предлог стандарда народне библиотеке 1975. године и саветовање у Ужицу, боље рећи договор требало је да дају смернице за рад и покрену формирање завичајних библиотека. Урађен је један упитник 1976. године, али са непотпуним бројем података. Народна библиотека Србије, вршећи анализу „Основне карактеристике стања народних библиотека у Србији ван територија САП у 1980. години са освртом на развој у периоду 1970-1980. години", у анкети која је спроведена укључена су и питања која се односе на завичајне библиотеке. На основу ове анкете добила се извесна слика о завичајним фондовима, иако не потпуна. „У односу на предходно стање било је помака у погледу укупног броја јединица грађе у завичајним фондовима, малог броја формирних каталога неколико библиотека које су почеле рад на завичајним библиографијама; али су укупни резултати, почев од броја формираних фондова, инвентарисања грађе, величине фонда и његове структуре, одсуства релевантних података о набавци и сарадњи са одговарајућим локалним институцијама, непостојање каталога и картотека, недостатак библиотечких радника за ангажовање на овим пословима, помањкање материјалних средстава и простора - били слаби и алармантни и задирали су у саму матичност. ${ }^{8}$ Зато Народна библиотека Србије у циљу помоћи народним библиотекама октобра 1982. године на саветовању у Нишу објављује Заједници матичних библиотека Методско упутство за формирање и вођење завичајних фондова у општинским народним библиотекама проф. др Десанке Стаматовић.

Основна намена овогУпутства била је да се дође до јединственог приступа, како би се обухватили сви радни процеси, предложио редослед решавања, односно почеци формирања завичајног фонда са свим његовим различитим збиркама, и да се разјасне нека спорна питања која нису само у домену општинских народних библиотека. ${ }^{9}$ Дати су конкретни одговори за превазилажење текућих

Ибид 5

Ибид 5, стр. 14

ибид 8 
проблема како би се извршиле припреме у својим срединама, договори са општинским органима око простора, територије, примерака, подстицање сарадње међу самим библиотекама, заједницама библиотека и другим културним установама музејима, архивима о разграничењу грађе.

Осамдесетих година урађени су истраживачки пројекти „Обим и структура библиотечке делатности у СР Србији ван ериторије САП у 1982. години" у овом пројекту упитнике су попуњавали библотечки радници свих типова библиотека и истрживачки тим Одељења за унапређивање библиотечке делатности. Резултати овог истраживања били су основа за будуће праћење развоја библиотека, а саопштено је на Републичком саветовању библиотечких и других радника из културе, науке, образовања и друштвених делатности у Земуну 1985. године. Упитници у оквиру овог пројекта односили су се и на завичајне фондове, али им није посвећивана већа пажња, примат је дат народним библиотекама. У оквиру овог пројекта поновљено је истраживање 1986. године када су се придружиле обе аутономне покрајине. Упитник који се односио на завичајне фондове био је боље формулисан и проширен. Нажалост подаци су због нестручности уништени. Тако да компарацију развоја завичајних фондова у периоду од 1982-1986. године је било немогуће урадити. Народна библиотека Србије је 1992. године, уз пуну сарадњу нове мреже општинских матичних библиотека, формулисала је и спровала анкету о библиотечком пословању, на основу које је формирана база података, и склопљена слика стања целокупне библиотечке делатности народних библиотека у Србији укључујући, заједно са детаљним упитником о завичајним фондовима. ${ }^{10}$ Ова база података названа је „Мрежа библиотека Србије“, а народне библиотеке имају обавезу да достављају годишње извештаје о свом раду. Значајни подаци о стању завичајних фондова прикупљају се путем базе „Мреже библиотека у Србији“. Иако је било много проблема око формирања и функционисања завичајних фондова према подацима из 1999. године од 192 општинске народне библиотеке 40 имају инвентарисану, обрађену и кроз систем каталога и картотека приступачну библиотечку грађу. „Још 27 библиотека агажовано је на

10 ибид 5, стр. 17 
пословима формирања завичајних фондова, утолико што је 17 библиотека тек инвентарисало грађу, док је у 10 библиотека фонд прикупљен, али грађа није инвентарисана."11 Укупно од 192 општинске народне библиотеке, 67 библиотека су завичајни фондови потпуно или делимично стручно организовани.

На Саветовању у Чачку је истакнуто да у оквиру 30 округа најбројније библиотеке са завичајним фондом су у јужнобанатском, средњебанатском, шумадијском, златиборском, подунавском и рашком округу. Никаквих активности нема у северобанатском, пчињском (осим Ваљева), моравичком (осим Чачка), топличком (осим Прокупља), у призренском и косовско-поморавском округу. У осталим окрузима слика је неуједнчена или нису дали податке о својм завичајним фондовима.

Законом о библиотечкој делатности Сл. Гласник РС број 34/1994. године завичајне збирке се уопште не спомињу. Библиотекари сматрају да стагнирање у формирању завичајног фонда у општинским народним библиотекама у Србији проузроковано новим Законом у коме се не предвиђа и нигде изричито не помињу обавезе библиотека да треба да имају завичајне збирке и завичајна одељења у свом саставу. ${ }^{12}$ На иницијативу библиотеке „Владислав Пековић Дис" из Чачка и Народне библотеке Србије 14. и 15. децембра 2000. године у Чачку је одржано Саветовање „Стање и перспективе развоја завичајних фондова“.

Закон о библиотечко-информационој делатности Сл. Гласник РС број 52/2011. У члану 6 тачка 5 стоји: „У библиотеци се може поред основног фонда, формирати и завичајна збирка."

\section{2. Прикупљање грађе}

Завичајна грађа једино може да се прикупља уколико се јасно поставе границе шта под њу потпада. Када се испуни овај основни предуслов, можемо деловати на пољу формирања и функционисања завичајног фонда. У дефиницији географске територије стоји „геофи-

11 Ибид 5, стр. 18

12 Наташа Ћуфић, Зборник стручних радова: Поморавско библиотекарство, Јагодина 2014. године 
зичка, политичка и аминистративна целина у садашњем времену“, зависно од друштвено-политичких промена и реорганизација општина. Општинским библиотекама, ранији закони, налагали су да сакупљају грађу за завичајне збирке са територије своје матичности. Међутим, у Законом о библиотекарству из 1994. године нису помињане завичајне библиотеке. Дошло је до недоумице и нејасноћа да ли су завичајне библиотеке требало да прошире границе своје завичајности на оруг или да и даље свака општинска библиотека негује свој завичајни фонд, да окружна библиотека остане у сегменту општинске библиотеке. После тридесет година постојања завичајних одељења урађен је упитник у 25 матичних бибилиотека Србије. Упитник је садржао пет питања: однос завичајности и матичности, обавезни примерак, каталошка обрада завичајне грађе и библиографски рад. Резултати су показали да од 25 анкетираних, седам њих прикупља завичајну грађу са територије читавог округа, шест није проширило оквире завичајности на терен своје матичности, а дванаест је одговорило да делимично прикупља грађу из читавог округа. Недоумица свакако не би било да је Закон из 1994. године обухваио и завичајне фондове. „Зато је од примарне важности да се територија са које се грађа сакупља, обрађује, проучава, публикује и популаризује не мења током времена без обзира на промене оквира матичности.

На саветовању у Нишу октобра 1982. године донети су закључци да се формира координационо тело које би планирало, оргзанизовало и стучно усмеравало формирање завичајних фондова заједно са општинским народним библиотекама. Закључци нису ни објављени уз материјал са Саветовања, Методско упуство није постало обавезно, сем што се овом проблему дискутовало на неколико саветовања. Координациони одбор није формиран, нити радне групе које би радиле на овом питању, Народна библиотека Србије, Заједница матичних библиотека, секретаријати, општине нису се ангажовали за одеређивање територија- подручја завичаја; нису донете одлуке општина о локалном обавезном примерку; успостављању сарадње и стручног разграничења врста грађе за фондове завичајних архива, библиотека и музеја. ${ }^{13}$

13 ибид 5, стр. 15 
Један од проблема оснивања завичајних фондова јесте простор. Према подацима из 1999. године од 67 библиотека са завичајним фондом или фондом у припреми, само 44 располажу са 82 просторије површине 1808 метара квадратних. Највећу површину имају библиотеке: Библиотека града Београда, Народна библиотека Панчево и Градска библиотека у Новом Саду, а најмања свега 2 метра квадратна у Гаџи Хану. Осталим библотекама за потребе завичајног фонда користе се просторије површине од 15-60 метара квадратних. „Ретке су библиотеке у Србији које имају адекватан простор довољан за своје потребе, па су и просторни капацитети издвојени за смештај и делатност завичајних одељења скромани у односу на задатке које треба да испуњавају." 14

Проф. др Десанка Стаматовић у свом Методском упутству за формирање и вођење завичајних фондова изричито наводи, да грађа завичајног фонда не сме бити у слободном приступу. „Такође, само коришћење грађе мора се обављати под неком врстом надзора од стране запослених. Ово су, поред осталог, начинили да се вредна грађа сачува." ${ }^{15}$

„У завичајним фондовима народних библиотека запослено је 55 библиотекара, 13 виших књижара и 11 књижничара. "16

Завичајне библиотеке обухватају:

- публикације краја независно од тога где је аутор рођен

- све публикације аутора рођених на тој територији, без обзира где су објављење

- све публикације издате у том граду/крају

Завичајне библиотеке сачињавају збирке књига, монографија, новина, часописа, каталога, магистарске радове, докторске дисертације и некњижне материјале: фотографије, разгледнице, плакате, новинске исечке, рукописе, аудио снимке, позивнице.

Грађа за завичајни фонд прикупља се на четири начина: обавезним примерком, сарадњом са појединцима, сарадњом са архивом, сарадњом са библиотекарима.

14 Ибид 2, стр. 40

15 Дејан Вукићевић, Корисници завичајних фондова, стр. 166, ICSL Годишњак међународног сусрета библиотекара слависта у Сарајеву 2008- 2009, https://www. ceeol.com/search/journal-detail?id=137 
Још је књаз Милош, када је отворена прва библиотека у Србији, наредио да се један примерак из сваке штапарије уступи библиотеци. Битно је да се законски регулише и за матичне библиотеке и завичајни фонд да бесплатни примерак. Посебно је проблем када је некњижна грађа у питању. Љиљана Брковић у свом раду из 1972. године, који се односи на обавезни примерак закључује да 5-10\% објављених књига не стиже у Народну библиотеку као обавезни примерак. У то време било је 26 регистрованих изавача, Народна библиотека је дошла до података да има још 20 предузећа која се баве издавачком делатношћу не рачунајући многе институције којима то није основна делатност. Данас појавом нових приватних издавача и штампарија нема увида колико је публикација издато. „Зато је за националну библиографију од великог значаја да завичајна одељења што потпуније региструју локалну продукцију ма какве тешкоће наилазила." ${ }^{17}$ Да ли завичајна одељења локална издања набављају путем обавезног примерка? На ово питање само су четири матичне библиотеке одговориле потврдно, у пет само неке штамапарије доставлају своју продукцију, а шеснаест библиотека се саме сналазе у набавци књига штампаних у своме месту. Из записника са састанка организационог одбора „Саветовања о завичајним фондовима“ (одржаног у Чачку 14. и 15. децембра 2000.године) први закључак је био: „Да се док се не донесе Закон о локалном обавезном примерку, група коју ће сачињавати Миломир Петровић, Десанка Стаматовић, Александра Вранеш и Радован Мићић, саставиће писмо које ће упутити свим библиотекама. Посебно писмо упутиће општинама."

На различите начине библиотеке долазе до бесплатног примерка приређивањем изложби штамапарско-издавачке продукције, представљањем најбољих остарења локалних издвача, успешна сарадња са ауторима, многи од њих не живе више на тој територији, али доносе своје књиге или друге публикације, културне манифестације које библиотека организује, пропаганду коју врше преко локалног радија, телевизије, новина, јавне захвалнице донаторима.

17 Марија Орбовић, Три деценије завичајног фонда, стр. 41, 3борник радова: Стање и перспецтиве развоја завичајних фондова, Бајић, Чачак, 2004. године 
Законом о обавезном примерку публикација Сл. гласник РС број 52 од 2011 у члану 3 тачка 2 стоји: „локални обавезни примерак" публикације који на основу овог закона издавач, односно други обвезник о свом трошку доставља јавној библиотеци Библиотеци града, односно општине у којој има седиште, пребивалиште, ради формирања и попуне завичајне библиотеке.

За фукционисање завичајних фондова поред материјалних средстава, стручног кадра, адекватног простора, читаонице и морају да постоје прецизно утврђени критеријуми за доследно и јединствено спровођење стандарда.

За Уређивање књижне грађе углавном није проблематично, али за некњижну има доста конфузије и неусаглашености. Завичајне библиотеке морају као и народне општинске бибилотеке да прате савремене технологије да се води месни и електронски алфабетски каталог према обиму завичајне грађе. Постављање електронског каталога је најсавременије средсво за проналажење података не само о завичајним фондовима већ о свим видовима библиотекачке грађе. „Укупно од 38 библиотека информације о власништву публикација укључује у опште инвентаре књиге, њих 44 води податке у једној самосталној инветарној књизи, а 32 библиотеке у посебним инвентарним књигама." 18

\section{1. Књижна грађа}

Књижну грађу завичајне збирке сачињавају књиге, монографије, периодична продукција, магистрскски радови и докторске дисертације.

Посебну пажњу имају старе и ретке књиге и фонд библиотека целина, оне представљају културне вредности од посебног значаја. „Са поменом приватних збирки аутоматски се намеће питање библиотека целина, тзв. спомен-библиотека, које истакнуте личности или чланови њихове породица остављају библиотеци на чување и коришћење." ${ }^{\prime 19}$ Библиотеку целину треба задржати у завичајном одељењу зато што је власник рођењем или својим стваралаштвом

18 Ибид 2, стр. 41

19 Ибид 3, стр. 63 
припадао том крају. Библиотеке целине најчешће садрже књиге и периодику на нашем и страном језику, старе и ретке књиге, рукописе објављених и необјављених дела, преписку и некњижну грађу: разгледнице, фотографије, албуме, картографску грађу, музикалије, архивску грађу, плакте, умрлице, лична докумнета, уметничке слике, личне предмете, делове намештаја, радне собе. ${ }^{20}$ „Било како да стижу и било где да су смештени, те библиотеке, најчешће знаменитих појединаца, чине библиотекарско и културно наслеђе. Уз њих се може сагледати и завичајна историја у малом; ту су често потписи, посвете, записи и печати. ${ }^{\prime 21}$

Према подацима са саветовања у Чачку 35 библиотека поседује 155 библиотека целина. Такви друштвено одговорни поступци су за сваку похвалу. Библиотека Српске академије наука и уметнсти - 30, Универзитетска библотека „Светозар Марковић“- 27, Библиотека Матице српске - 27 и Народна библотека Србије - 14. Законом о задужбинама, фондацијама и фондовима Сл. Гласник СРС број 59-1989. године овим Законом утрђени су циљеви ради којих се задужбине и фондови могу оснивати, као и начин оснивања и управљања.

Одељење завичајне периодике је од велике важности у завичајном фонду. „Нису само часописи из области књижевности, науке и уметности хроничари данашњег културног тренутка, то су у једнакој мери, а са мањом пажњом и признавањем јавности, дневне новине, листови и ситна гласила. Када се за њих не би везивала пажња библиографа и завичајног библиотекара, мноштву драгоцених и разнородних сазнања временом би се загубио траг.“22 Захваљујући библиографији завичајне периодике једне Крагујевачке новине сачуване су и пронађене у Загребу. Серијске публикације формиране су од одређеног броја периодичних гласила.

Дилема постоји када су у питању завичајни писци, ако су основне одреднице да су аутори

а) рођени на одређеној територији

20 Слободан Радовић, Легати и фондови, стр. 82, 3борник радова: Стање и перспецтиве развоја завичајних фондова, Бајић, Чачак, 2004. године

21 Ибид 20, стр. 88

22 Ибид 3, стр. 38 
б) живе или су живели на одређеној територији ${ }^{23}$

Како ти аутори живе на другој територији, за разлику од места рођења или су се селили у више места дешава се да их сматрају својим сви градови у којима су живели.

\section{2. Некњижна грађа у завичајним збиркама}

Некњижна грађа је од посебне важности и сачињена је од специфичне и карактеристичне заоставштине за тај крај, која има посебну историјску, културну и музејску вредност.

Посебни фондови обухватају следеће збирке некњижног материјала:

- збирку књижевних рукописа и архивалија

- графичку збирку (графички листови и мапе, уметнички плакат)

- збирку фотодокумената (фотографије, колекционарски и издавачки албуми и разгледнице)

- збирку музикалија и мултимедија (нотне публикације, грамофонске плоче, звучне и видео касете, компакт дискови, цд-ром)

- картографску збирку (карте, планови, градова, атласи, рељефи)

- збирку документационог материјала (плакати, леци, адресари, именици, каталози, водичи, календари, позивнице, проспекти...)

Набавка посебних збирки врши се кроз обавезни примерак, поклон, куповином и разменом. Због својих специфичности и разноликости постоје одређени проблеми код инвентарисања и складиштења некњижне грађе. Рукописна и архивска грађа је посебно вредна и драгоцена зато је треба посебно неговати. „Рукописна и архивска грађа истовремено су и ризница информација о појединцима и о завичају уопште.“24 Рукописне грађе узавичајним одељењима су специфичне и разликују се од општих фондова народне библиотеке. На саветовању у Чачку 2000. године речено је да „стручна обрада рукописне грађе, вероватно због своје коплексности није подлегла одговарајућим

23 Нинослава Милановић, Проблеми у успостављању завичајног фонда, стр. 46, 3борник радова: Стање и перспецтиве развоја завичајних фондова, Бајић, Чачак, 2004. године 
међународним стандарима. “25 Начињен је програм који може да одговори захтевима, а употеба поједностављена и применљива. „Сваки аутограф, без обзира да ли је писан руком, или писаћом машином, да ли је први примерак, копија са испаравкама, препис „на чисто“, лични или туђи, превод, интегралан текст, или вештачка целина, целовит или фрагментаран, представља духовни производ и доследност описивања карактеристике чијем остваривању тежи сваки озбиљан библиограф, који налазећи се пред различитим рукописима исте дилеме треба да решава на исти начин. Нека инцијална решења на том путу можда нуди програм АРХЕИОН. ${ }^{26}$ Овај прогам примењен је у обради рукописне заоставштине Десанке Максимовић.

Некњижна грађа одражава карактеристике етничког, географског, историјског простора на коме су настале. Зато је посебан задатак завичајних фондова да ове драгоцене вредности сачувају. Прво обезбедити адекаватан простор, затим температуру, влажност ваздуха, примерену светлост. Редовна провера влаге и температуре у депоима. Често овај материјал се сређује по групама. Плакати се обично распоређују по тематици коју обрађују, затим по години излажења, дешава се да је без импресума, па се време и локацију мора истраживати.

Предметно разврставање захтева стучно образовање. У анкети је рађења са циљем да прикаже реално стање у којој мери се прикупља некњижна грађа у завичајним библиотекама, показала је да некњижну грађу само 17 само прикупља, 8 и инвертарише, а 5 каталошки обрађује и то само фотографије, разгледнице, рукописе и музикалије.

„Звичајни фондови су добро истовремено неопходно место за проучавање индивидуалне, породичне, локалне и регионалне историје ". ${ }^{27}$ Готово да нема предмета који се не би могли организовати кроз различите видове активности: радионице из одређених обасти, такмичења, квизове, писање на одређену тему, ликовне радове, изложбе, прављење зидних новина... То може да буде и медијски пропраћено, да се укључе и родитељи било као посматрачи или као учесници, посебно ако је неко од родитеља по занимању из сличне области.

\footnotetext{
25 Ибид 24

26 Ибид 3, стр. 65

27 Ибид 15, стр. 163
} 
Према пројекту Мреже библиотекара Србије од 158 библиотека обухваћених анкетом Народне библиотеке Србије, само 26 њих има објављене монографије о завичају, а њих 10 друге публикације које се односе на поједине институције у завичају. Популарисањем сопствених фондова бави се свега око 30\% библиотека: изложбе приређује 60 библиотека, предавања у вези са завичајем организује 31 установа културе, информације о завичају у облику филмова нуди 31 библиотека, а у оквиру других медија њих укупно 56.

\section{Закључак}

Завичајне библиотеке имају задатак да сачувају прошлост за будуће генерације. Како би се континуирано, предано, стручно прикупља и сачувала материјална/писана документа из прошлог времена за будућност. Завичајне библиотеке су центри културног дешавања свога краја. Оне су ризнице историје свога краја и сегмент националне историје. Завичајни фонд је скуп културог наслеђа једног краја. Оне негују духовне различитости народа. Представљају мостове са локалном и националном заједницом. Наилазило се на различите проблеме од простора, кадра, неразумевања средине, материјалних средсатава, начина вођења завичајне грађе.

Завичајне библиотеке морају на разне видове да скрену пажњу на своје постојање и користите сваку повољну прилику да отворе своја врата и скрену пажњу на себе, да афирмишу завичај и његове културне вредности јавности. Посебно је значајно да се деца укључују, упознају и мотивишу на различите начине сходно њиховом узрасту уз стручну помоћ библиотекара предметног и разредног наставника да буду корисници завичајних библиотека.

\section{Литература}

Вранеш, Александра, Љиљана Марковић, Јасна Јанићијевић, Етичност у науци и култури, Филолошки факултет Универзитета у Београду, Белпак, 2009. године Вранеш, Александра, Љиљана Марковић, Љиљана Бајић, Стана Смиљковић, Школа 
и библиотека, Филолошки факултет Универзитета у Београду, Белпак, 2010. године

Вранеш, Александра, Рукописна грађа у завичајним фондовима, Зборник радова: Стање и перспецтиве развоја завичајних фондова, Бајић, Чачак, 2004. године

Вукићевић, Дејан, Корисници завичајних фондова, ICSL Годишњак међународног сусрета библиотекара слависта у Сарајеву 2008-2009, Веб 10.9.2017. године https://www.ceeol.com/search/journal-detail?id=137

Милановић, Нинослава, Проблеми у успостављању завичајног фонда, Зборник радова: Стање и перспецтиве развоја завичајних фондова, Бајић, Чачак, 2004. године

Орбовић, Марија, Три деценије завичајног фонда, Зборник радова: Стање и перспецтиве развоја завичајних фондова, Бајић, Чачак, 2004. године

Радовић, Слободан, Легати и фондови, Зборник радова: Стање и перспецтиве развоја завичајних фондова, Бајић, Чачак, 2004. године

Стаматовић, Десанка, Завичајни фондови данас, Зборник радова: Стање и перспецтиве развоја завичајних фондова, Бајић, Чачак, 2004. године

Ћуфић, Наташа, Зборник стручних радова: Поморавско библиотекарство, Јагодина, 2014. године 